\title{
The Effect Of Work Satisfaction And Work Discipline On Service Performance At Atmedika Hospital In Palopo City
}

\author{
Pratiwi Bustami ${ }^{1}$, Muhammad Aqsa ${ }^{2}$, Muchtar Surullah ${ }^{3}$ \\ \{pratiwilanteng@student.umpalopo.ac.id¹,muhammadaqsa@umpalopo.ac.id², \\ muchtarsurullah@umpalopo.ac.id\} \\ Postgraduate of Management, Universitas Muhammadiyah Palopo \\ Jalan Jendral Sudirman Km. 3. Binturu Kota Palopo, 91922, Indonesia
}

\begin{abstract}
This study aimed to determine the effect of job satisfaction and work discipline on service performance at Atmedika Hospital in Palopo City. The research approach was a quantitative method with Statistical Package for Social Science (SPSS) 21 software assistants and the number of respondents in this study was 68 people. The sampling technique was probability sampling with primary data types in the form of questionnairesr. The results showed that job satisfaction and work discipline had a significant influence on service performance at Atmedika Hospital in Palopo City. Thus in improving service performance can be done by increasing employee job satisfaction and increasing work discipline.
\end{abstract}

Keywords: job satisfaction, work discipline, service performance

\section{Introduction}

Human Resources (HR) is one of the determinants in efforts to maintain the sustainability of an organization [1]. The existence of human resources that are continuously made efforts to improve quality will have an impact on improving performance in an organization so that it can bring progress to the organization [2]. Kperformance is considered capable of influencing the sustainability of the organization because it can provide satisfactory results for the organization. There are several factors that affect performance improvement including the existence of job satisfaction factors and work discipline factors, both of these factors empirically indicate that it has an influence on service performance, these results are consistent with research conducted [3].

The efforts to improve quality of job satisfaction and increase work discipline will have an impact on service performance [4]; [5]. Job satisfaction can be interpreted as an expression of someone's reaction about what he is doing and a figure of where he works. Decisions are individual because each person can be different in expressing satisfaction. Previous similar studies have been carried out by [6] which explains that job satisfaction affects employee performance. Another factor is work discipline which shows attitude in doing everything with positive behavior [7]. The work discipline shown by the employee is responsible for all the tasks that are carried out by the company or institution where they work. Previous research conducted by [8] also shows the results that work discipline affects employee performance.

Atmedika Hospital is one of the hospitals in Palopo which is oriented towards community service. The number of hospitals in Palopo city which is quite a lot forced the management to 
compete in improving the performance of their services so that service users in this case are pesien and the patient's family feels their needs are fulfilled so that Atmadika hospital can survive and continue to grow to become one of the referral hospitals in the city Palopo in particular and Luwu Raya in general. This is important to do considering that the hospital today is a public facility that must be managed properly so that customers feel comfortable with the services provided.

Based on the background above, this study was conducted with the aim of analyzing and identifying the effect of both parisally and simultaneously job satisfaction and work discipline on the performance of employee services at Atmedika Hospital in Palopo City. The formulation of the problem that can be submitted is: How do the effects of job satisfaction and work discipline on service performance at Atmedika Hospital, Palopo City.

\section{Literature Review}

\subsection{Job satisfaction}

Job satisfaction is an expression of attitude that leads to a sense of fun or an expression of an unpleasant attitude that is felt and shown by employees in managing their work [9]. This study measured job satisfaction through several indicators including psychological, social, physical and financial factors [10].

\subsection{Work discipline}

The sustainability of an organization can also be determined by the work discipline owned by employees. Work discipline is able to encourage employees to maximize their abilities based on the applicable rules [11]. Indicators in work discipline are the ability, leadership model, supervision, assertiveness and penalty sanctions [12].

\subsection{Service Performance}

Service performance is the ability to actualize employees in carrying out responsibilities in accordance with guidelines or technical instructions [13]. Indicators of service performance are quality, quantity, timeliness and cost effectiveness [14].

The following is a conceptual framework for this research:

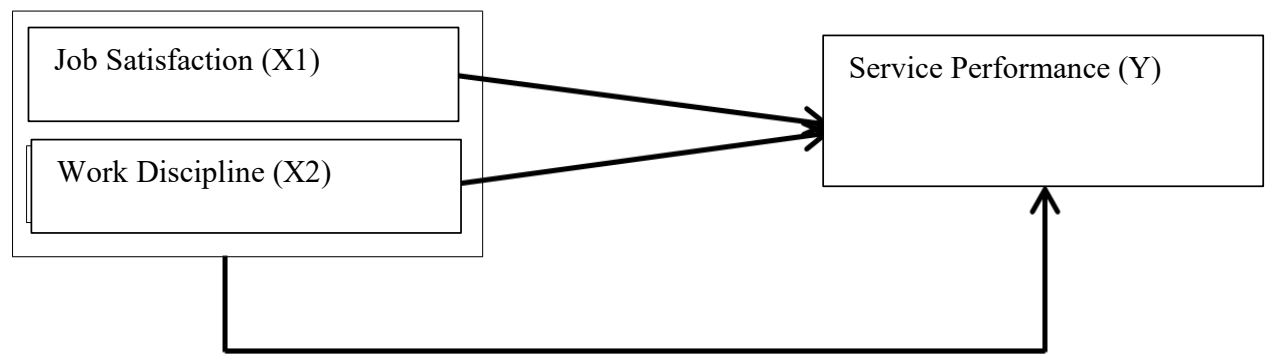

Fig.1. Conceptual Framework 


\section{Hypothesis}

The hypothesis in this study:
$\mathrm{H}_{1} \quad$ : Partially, job satisfaction has an effect on service performance at Atmedika Hospital in Palopo City
$\mathrm{H}_{2}$ : Partially, work discipline influences the performance of services at Atmedika Hospital in Palopo City
$\mathrm{H}_{3}$ : Simultaneously, job satisfaction and work discipline affect the service performance at Atmedika Hospital in Palopo City

\section{Method}

This research was conducted with the aim to identify the effect of each independent variable in the study and to know how much its influence on the dependent variable. The independent variables in this study were job satisfaction and work discipline while the dependent variable in this study was service performance. The method of this research was descriptive quantitative, conducted at Atmedika Hospital in Palopo City, South Sulawesi. Research time since April 2020 - June 2020. The population of this study was all the employees of Atmedika Hospital in Palopo City namely 83 employees. The sampling technique was done by purposive sampling method. The method of data collection was collected by giving questionnaires to the number of samples. This study applied several tests including the testing of instruments that were validity and reliability. Classic assumption tests include tests of normality, multicollinearity, heteroscedasticity and autocorrelation. Partial test or $\mathrm{t}$ test, simultaneous test or $\mathrm{f}$ test and coefficient of determination test (R2).

\section{Result And Discussion}

\subsection{Multiple linear regression analysis}

Table 1.Regression coefficient

\begin{tabular}{cccc}
\hline \multirow{2}{*}{ Model } & \multicolumn{2}{c}{ Unstandardized Coefficients } \\
\cline { 3 - 4 } & & $\mathrm{B}$ & Std. Error \\
\hline \multirow{3}{*}{1} & (Constant) & 18,038 & 2,120 \\
& Job Satisfaction &, 190 &, 094 \\
& Work Discipline &, 204 &, 083 \\
\hline \multicolumn{3}{c}{ Source: data processed, 2020 }
\end{tabular}

It Can be seen based on table 1, the regression equation is as follows:

$$
\mathrm{Y}=18,038+0,190 \mathrm{KK}+0,024 \mathrm{DK}
$$

Referring to the results of the regression equation above then:

$\alpha=$ constant $=18,038$

it means that if all independent variables are $=0$ then the service performance will remain at 18,038. So that, there are other factors that influence the performance of Atmedika Hospital services in addition to job satisfaction and work discipline. 
$\mathrm{b} 1=$ regression coefficient for $\mathrm{X} 1=0,190$

the beta coefficient gives a positive result of 0.190, indicating that at Atmedika Hospital if it is assumed that the variable $\mathrm{x}$ is constant then the amount of job satisfaction and work discipline is 0.190 .

$\mathrm{b} 2=$ regression coefficient for $\mathrm{X} 2=0,204$

the beta coefficient gives a positive result of 0.204 , indicating that in Atmedika Hospital if it is assumed that the variable $\mathrm{x}$ is constant, then the amount of job satisfaction and work discipline is 0.204 .

Table 2. T test results

\begin{tabular}{|c|c|c|c|}
\hline & Model & $\mathrm{T}$ & Sig. \\
\hline \multirow{3}{*}{1} & (Constant) & 8,508 &, 000 \\
\hline & Job Satisfaction & 2,012 & 047 \\
\hline & Work Discipline & 2,463 & 016 \\
\hline
\end{tabular}

$\mathrm{T}$ test analysis results can be shown based on the value at the level of significance, if the value of the probability of t-count <value (alpha) 0.05 , it can be concluded that the independent variable has a significant effect on the dependent variable. The results of the analysis in table 2 show that the probability value of job satisfaction is 0.047 which indicates that the value is $<0.05$ so it can be concluded that job satisfaction has a positive effect on service performance. Thus increasing job satisfaction will have an impact on improving service performance. The value of work discipline probability is 0.016 , which indicates that the value is $<0.05$ so that it shows a positive influence on service performance. Thus increasing work discipline will have an impact on improving service performance.

Table 3. Test results $f$

\begin{tabular}{ccccccc}
\hline & Model & Sum of Squares & Df & Mean Square & F & Sig. \\
\hline \multirow{4}{*}{1} & Regression & 5,745 & 2 & 2,872 & 4,881 &, $010^{\mathrm{b}}$ \\
& Residual & 48,255 & 82 &, 588 & & \\
& Total & 54,000 & 84 & & & \\
\hline \multicolumn{6}{c}{ Source: data processed, 2020 }
\end{tabular}

The results of the $\mathrm{F}$ test analysis show that the F-statistical probability with a real degree of 5 percent obtained a result of 0.010 that the independent variables jointly had an influence on the dependent variable.

Table 4. Determination coefficient test results

\begin{tabular}{cccccc}
\hline Model & $\mathrm{R}$ & $\mathrm{R}$ Square & $\begin{array}{c}\text { Adjusted R } \\
\text { Square }\end{array}$ & $\begin{array}{c}\text { Std. Error of the } \\
\text { Estimate }\end{array}$ & Durbin-Watson \\
\hline 1 &, $326^{\mathrm{a}}$ &, 106 &, 085 &, 767 & 2,087 \\
\hline \multicolumn{5}{c}{ Source: data processed, 2020 }
\end{tabular}

The calculation results obtained $\mathrm{R}$ square results 0.106 or 10.6 percent means that 10.6 percent of the ups and downs of service performance is influenced by job satisfaction and work discipline. 


\subsection{Job satisfaction affects service performance}

The probability value of job satisfaction is 0.047 indicating that the value $<0.05$ so it can be concluded that job satisfaction has a positive influence on service performance. Thu,s it can be explained that increased job satisfaction will have an impact on improving service performance. The results of this study are consistent with research conducted by [15] who find that job satisfaction felt by employees has a positive influence directly and indirectly through employee performance on customer satisfaction. [16] in his research explained that employees who interact directly with consumers conducted with the aim to build awareness and a good response based on the consumer needs. The efforts to provide satisfaction to consumers will have an impact on improving services performed by employees to consumers [17] explains that employees will reach the point of satisfaction at work so it will increase satisfaction and loyalty to customers.

\subsection{Work discipline has an effect on service performance}

The probability value of work discipline is 0.016 , which means $<$ of 0.05 , so it can be concluded that work discipline has a positive influence on service performance. Thus, it can be explained that increasing work discipline will have an impact on improving service performance. The results of this study are consistent with research conducted by [18] explain that work discipline has an influence on service performance. Work discipline really has an influence on patient satisfaction, good work discipline will directly help patients in health care activities [19].

\section{Conclusion}

Job satisfaction felt by employees can increase employee motivation and performance in carrying out their obligations in the organization because employees feel that what they give or sacrifice is what they get, either in the form of a salary or reward. In addition, discipline in doing everything an employee's obligation also affects their performance in the organization, with high discipline it will make employees more effective and optimal in carrying out their duties so that what is the organizational goal can be achieved.

\section{Acknowledgments}

Dr. Muhammad Aqsa, S. Kom. M. Si., For the knowledge and guidance so that this article can be finished.

\section{References}

[1] Rusanto, O., \& Saputra, N. E. (2019). Pengaruh Kualitas Pelayanan Dan Disiplin Kerja Terhadap Kepuasan Masyarakat Pada Kantor Lurah Klender Jakarta Timur. Widya Cipta: Jurnal Sekretari Dan Manajemen, 3(1), 7-16. 
[2] Sahangggamu, P. M., \& Mandey, S. L. (2014). Pengaruh Pelatihan Kerja, Motivasi, Dan Disiplin Kerja Terhadap Kinerja Karyawan Pada Pt. Bank Perkreditan Rakyat Dana Raya. Jurnal Emba, 2(4), 514-523.

[3] Nisyak. (2016). Pengaruh Gaya Kepemimpinan, Motivasi Dan Disiplin Kerja Terhadap Kinerja Karyawan Surabaya. Urnal Ilmu Dan Riset Manajemen.

[4] Ardana, K. M., \& Sriati, A. A. (2012). Buku Ajar Perilaku Keorganisasian. Denpasar: Graha Ilmu.

[5] Indrawati, A. D. (2013). Pengaruh Kepuasan Kerja Terhadap Kinerja Karyawan Dan Kepuasan Pelanggan Pada Rumah Sakit Swasta. Jurnal Manajemen, Strategi Bisnis, Dan Kewirausahaan, $7(2)$.

[6] Suharnomo, K. D., \& Ratnawati, I. (2010). Pengaruh Kepuasan Kerja Terhadap Kinerja Karyawan Dengan Komitmen Organisasional Sebagai Variabel Intervening (Studi Pada Rsud Tugurejo Semarang).

[7] Susanto, \& Natalia. (2019). Pengaruh Motivasi Kerja, Kepuasan Kerja, Dan Disiplin Kerja Terhadap Kinerja Karyawan Pada Divisi Penjualan. Agora, 7(1).

[8] Azwar, S. (2015). Penyusunan Skala Psikologi (2nd Ed.). Yogyakarta: Puataka Belajar.

[9] Arda, M. (2017). Pengaruh Kepuasan Kerja Dan Disiplin Kerja Terhadap Kinerja Karyawan Pada Bank Rakyat Indonesia Cabang Putri Hijau Medan. Jurnal Ilmiah Manajemen \& Bisnis, 18(1), 45-60.

[10] Sutrisno, E. (2011). Manajemen Sumber Daya Manusia. Jakarta: Kencana.

[11] Hidayat, Z., \& Taufiq, M. (2012). Pengaruh Lingkungan Kerja Dan Disiplin Kerja Serta Motivasi Kerja Terhadap Kinerja Karyawan Perusahaan Daerah Air Minum (Pdam) Kabupaten Lumajang. Jurnal Wiga, 2(1).

[12] Safitri, E. (2013). Pengaruh Pelatihan Dan Disiplin Kerja Terhadap Kinerja Karyawan. Jurnal Ilmiah Manajemen, 1(4).

[13] Sinambela, L. P. (2012). Kinerja Pegawai. Yogyakarta: Graha Ilmu.

[14] Kaswan. (2012). Manajemen Sumber Daya Manusia Untuk Keunggulan Bersaing Organisasi. Yogyakarta: Graha Ilmu.

[15] Indrawati, A. D. (2013). Pengaruh Kepuasan Kerja Terhadap Kinerja Karyawan Dan Kepuasan Pelanggan Pada Rumah Sakit Swasta. Jurnal Manajemen, Strategi Bisnis, Dan Kewirausahaan, $7(2)$.

[16] Bulgarella, C. C. (2005). Employee Satisfaction \& Customer Satisfaction : Is There A Relationship? Whita Paper Guide Star Research For Better Business Relationships.

[17] Robbins, S. P. (2006). Perilaku Organisasi. Edisi Kesepuluh, Edisi Lengkap. Jakarta: Pt Indeks.

[18] Saputra, (2019). Pengaruh Kualitas Pelayanan dan Kedisiplin Pegawai Terhadap Kepuasan Masyarakat Pada Kantor Lurah Klender Jakarta Timur, 3 (1)

[19] Yunanto, Y. (2016). Analisis Pengaruh Kualitas Pelayanan Dan Disiplin Kerja Karyawan Terhadap Kepuasan Pasien Askes Di Pt Askes Kediri. Jurnal Ekonomi Universitas Kediri, 1(1), 26-37 